Because of the fact that we have straight lines here, this holds good for all light intensities.

In figure 6 we have plotted transpiration rate against stomatal aperture at constant energy supply. This gives the familiar picture which can also be found in most textbooks. According as the stomatal aperture increases, the increase in transpiration rate becomes flattened.

Summarizing we arrive at the conclusion that it is not possible to find a simple proportionality between transpiration rate and energy supply. This makes it clear that there is much more in the process than mere physical evaporation. Although the rate of water loss is partially governed by physical factors in the environment, in much the same way as this is the case with evaporation from a water surface, frequently there exist notable differences from the former phenomenon.

The stomatal aperture as well as the energy supply is important in determining transpiration rate, but the relationship between these two factors and the transpiration is a rather complex one, because of the interaction of light intensity and stomatal aperture, as the one factor, light intensity, has a distinct influence on the other factor, stomatal aperture.

If in agricultural practice the transpiration is found to be proportional to radiant energy we have to assume that in the different observational periods equal mean stomatal apertures have occurred.

\title{
TRANSPIRATION OF GLASSHOUSE TOMATOES, LETTUCE AND CARNATIONS
}

\author{
F. E. NEALE \\ National Institute of Agricultural Engineering, Silsoe, England
}

\begin{abstract}
SUMMARY
The relationship between the transpiration from glasshouse crops and the total inconing radiation is shown graphically for tomatoes, lettuce and carnations. Daily values of transpiration and radiation are plotted for all three crops, the results including readings taken in winter as well as summer months and also illustrating the effect of incomplete vegetative cover of the glasshouse area. In addition hourly values of radiation and transpiration of tomatoes and carnations measured over two-day periods during the summer, are presented.
\end{abstract}

\section{INTRODUCTION}

The purpose of this contribution is to provide some experimental results on the transpiration of glasshouse crops, and to emphasize the high correlation of daily and hourly values of transpiration with tolat radiation from the sun and sky. It is hoped that the data will usefully supplement results already obtained for outdoor crops by PENMan and others. No attempt is made here to discuss the results in the light of the theoretical work of Pennan (1948), Thonnthwaite (1948), and DE VRIEs et al. (1953, 1954). Attention is directed rather to the 


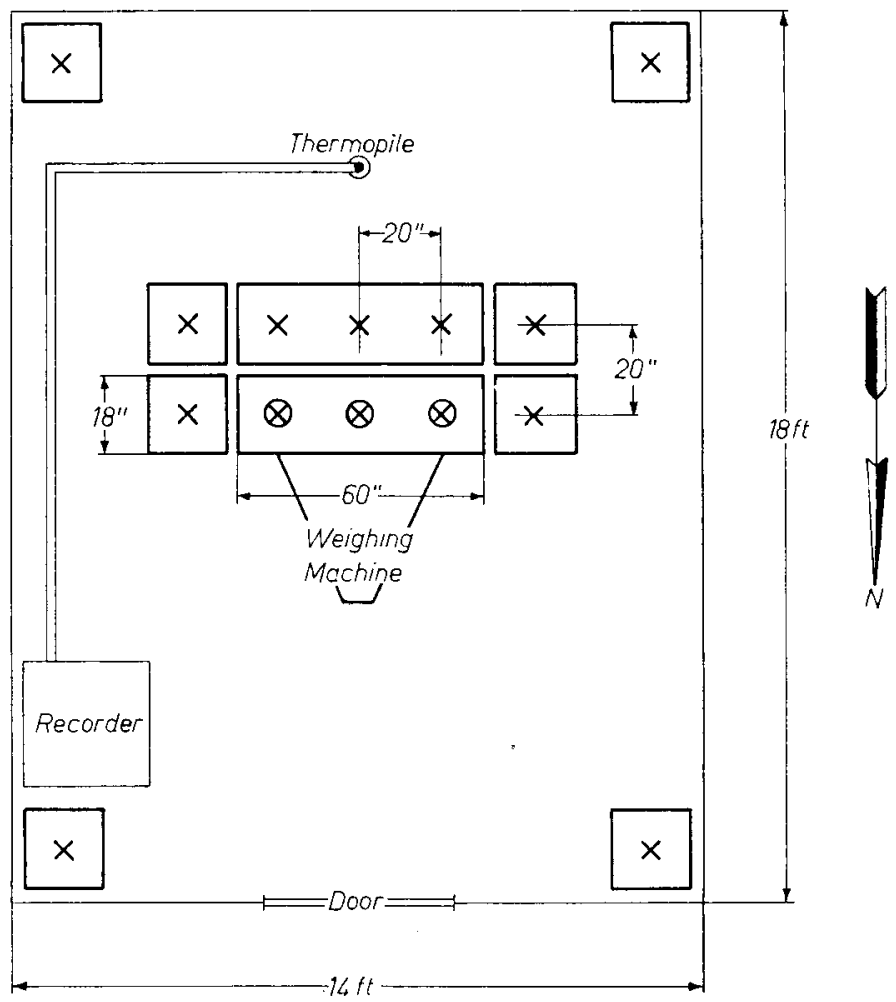

Fig. 1. Layout of 1952 tomato transpiration experiment. Plan view. Positions of plants DENOTED BY CROSSES, AND THE EXPERIMIENTAL ONES ARE RINGED.

experimental methods used in measuring the two most important quantities in the energy balance equation for a glasshouse - the incoming radiation and the transpiration, and the accuracy attainable.

\section{General description}

Transpiration measurements have been made at the National Institute of Agricultural Engineering for some three years, on three glasshouse crops tomatoes, lettuce and carnations. The crops were grown in a small BYron (metal construction) glasshouse, $5.5 \mathrm{~m}$ long and $4.3 \mathrm{~m}$ wide. In the middle of the house was a deep rectangular box, $152 \mathrm{~cm} \times 51 \mathrm{~cm}$ (plan), filled to the top with soil and containing a number of plants arranged to form part of a uniformly spaced layout in the house. The box and contents (weighing about $500 \mathrm{~kg}$ ) were supported by flexible pivots on one arm of a weighing machine, and were balanced by standard brass weights at the other end of a double lever balancing system. To determine the total evaporation from the box area during any given period, the box and contents were balanced at the beginning and end of the period and the quantity of irrigation water added was noted. In practice the routine was simplified by adding to or removing brass weights placed on the edge of the box itself, the counterbalance weights being left constant. The machine was sensitive to changes in weight of $10 \mathrm{~g}$ or better, which corresponds to an evaporation of about $0.013 \mathrm{~mm}$ of water. Total radiation was measured by means of a Moli-type thermopile (by KipP en Zonen). 


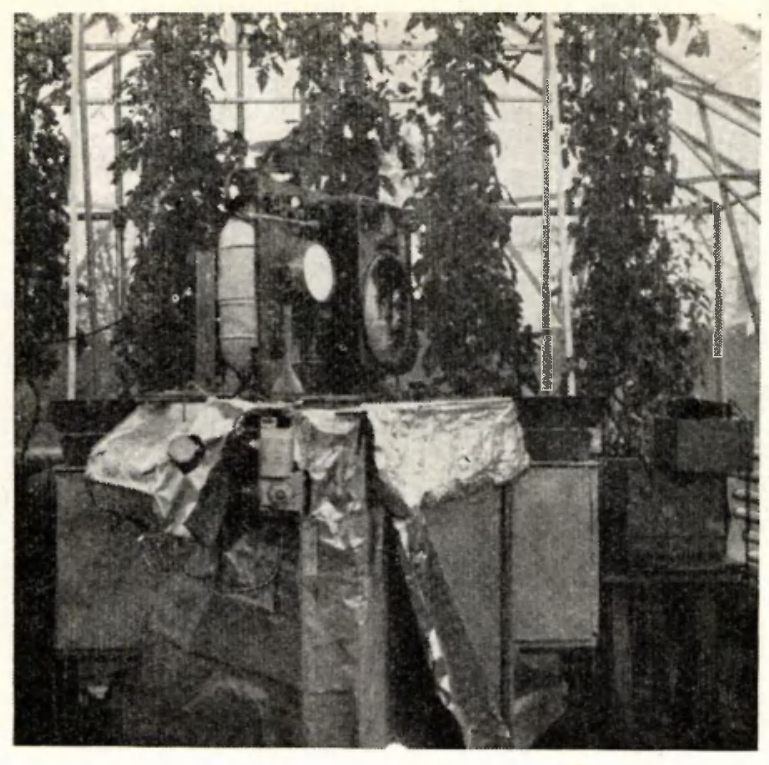

Fig. 2. VIEW OF WEIGHING

MACHINE FROM NOHTH SIDE. Aluminium FOIL PHOTECTS THE BALANCING MECHANISM FROM SOLAR Radiation. Pluants on THE SOUTH SIDE OF THE EXPERIMENTAL PLANTS WERE REMOVED FOR THIS PICTURE, TAKEN OCtOBER 1952.

At first the output from the thermopile was recorded on a $0-10 \mathrm{mV}$ potentiometric recorder printing every 33.3 seconds. The resulting trace had then to be integrated with respect to time. This rather laborious procedure was avoided in later experiments by connecting the thermopile to the input of a magnetic amplifier (by Electro Methods LTD.) the output of which drove an integrating motor-counter unit.

The layout and equipment used are shown in Figures 1-4.

\section{RESULTS AND DISCUSSION}

(a) Tomatoes, 1952. The equipment used for this experiment is shown in Figures 1 and 2. Readings were taken daily from the end of June to the beginning of November. Some results are shown in Figure 5 in which both the evaporation and the radiation are expressed in millimetres of water. Each quantity is represented as a series of points equally spaced in time, but the values actually refer to periods of 24 hours \pm 20 minutes, commencing at a mean time of 9.30 a.m. each day (B.S.T.). Thus in speaking of "daily" values of evaporation and radiation the error involved is one of definition only, and is unimportant providing the two quantities are measured over the same period.

The evaporation from the experimental plants and soil was with few exceptions greater than the corresponding radiation, and the ratio - observed evaporation in $\mathrm{mm}$ water/radiation expressed in equivalent $\mathrm{mm}$ water, increased as the season progressed. (On one hot day, July 22nd, the evaporation was exceptionally low compared with the radiation; this was due to deliberate heavy damping down of the glasshouse on this occasion).

Rough calculations show that of the total radiation falling on a uniform glasshouse crop only about half is available for evaporating water from the plants and soil, the remainder being partly reflected, partly returned as long wave radiation (though this is smaller than for an outside crop), and partly transferred as sensible heat to the ventilating air. Therefore in a house with a uniform vegetative cover over a large horizontal area the evaporation each 
Fig. 3. The Weighing Machine AND BOX CONTAINING THE EXPERIMENTAL PLANTS ARE IN THE LEFT CENTRE OF THE PICTURE. VIEW FROM SOUTH-WEST CORNER, TAKEN JAN. 19TH, 1953.

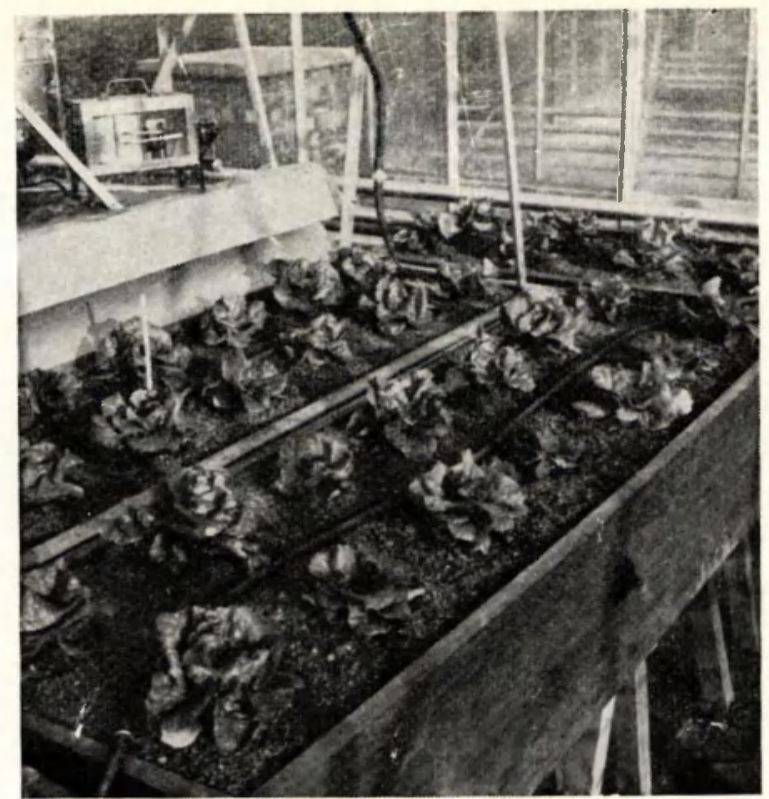

day should be considerably less than the radiation values given in Figure 5 . The numerical proximity of the evaporation and transpiration values we observed in June, July, and August was therefore fortuitous. The high evaporation values and the increasing value of the ratio - evaporation/radiation was probably due to the large vertical extent of the experimental plants in comparative isolation - despite the presence of adjacent plants on the east, south and west sides of the weighing machine. Here it may be noted that the plants occupied only $16 \%$ of the total area of the house.

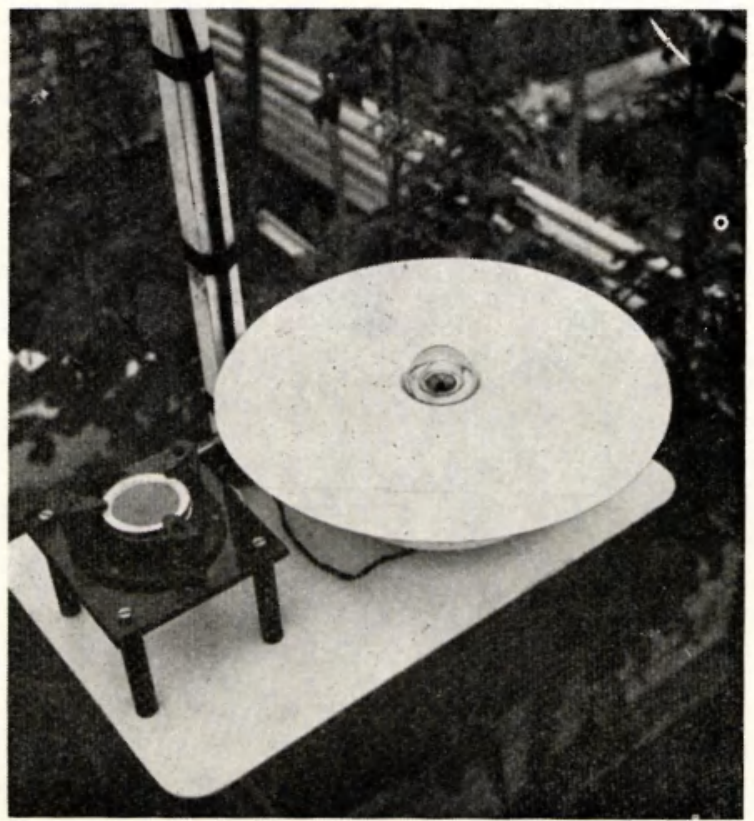

Fic. 4. SHowing THEIrMopile (RIGHT) USED FOR MEASUREMENT OF THE TOTAL RADIATION FROM THE SUN AND SKY. (THE PHOTOCELL ON THE LEFT WAS USED FOR LIGHT MEASUREMIENTS). 
Random errors are calculated to be about $\pm 5 \%$ in the measurement of evaporation and $\pm 4 \%$ in the measurement of the radiation, for this experiment.

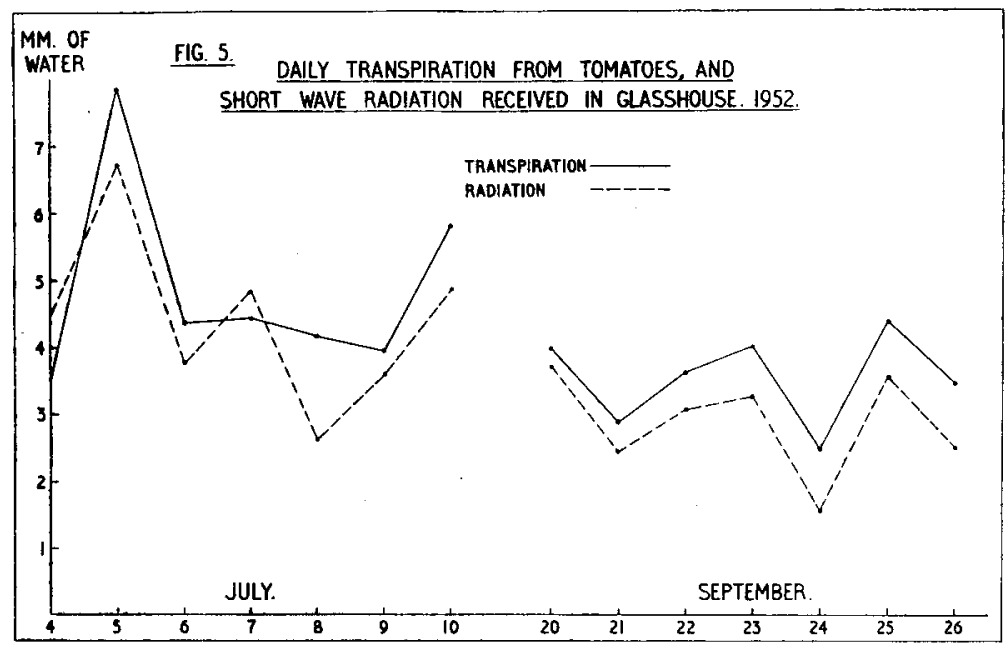

(b) Winter Lettuce, 1952-1953. The measurements on lettuce were similar to those in the 1952 tomato experiment. Figure 3 shows the arrangement used and illustrates the drip irrigation system which was installed to avoid the time-consuming operations of hand watering. The results obtained and plotted in Figure 6 still show a correlation between the evaporation and total radiation, but the values obtained are of a quite different order of magnitude from the 1952 summer experiment. The low evaporation values are probably due in this case to the fact that at no time during their growth did the lettuce completely cover the soil. Further, with the drip irrigation system the unshaded soil was generally quite dry at the surface.

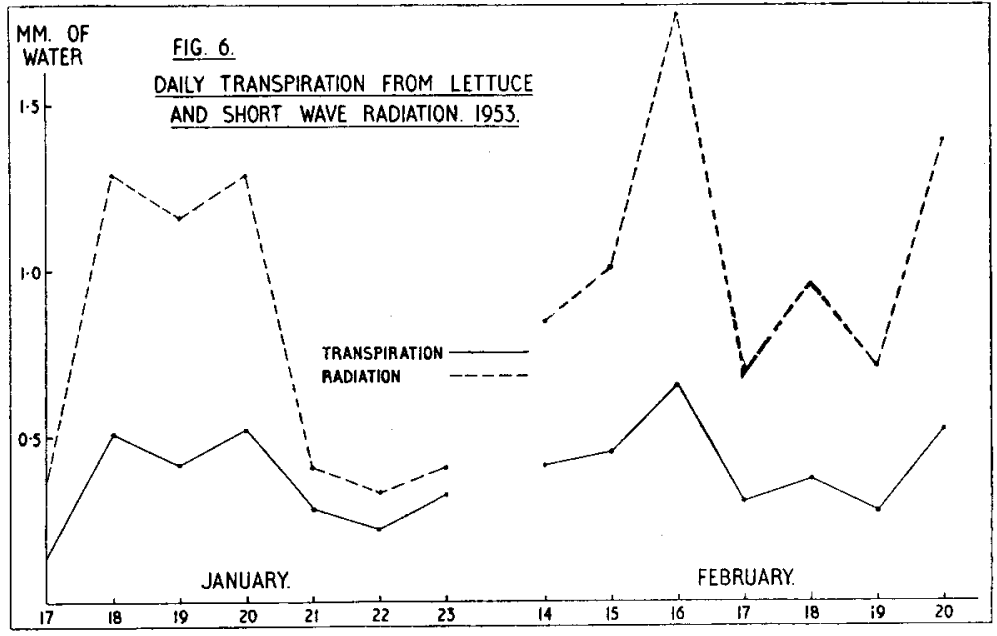

Random errors in the measurement of evaporation were calculated to be about $\pm 7 \%$ in this experiment, and $\pm 4 \%$ in the radiation measurements as before. 
Fig. 7. Tomato thanspiration EXPERIMENT, 1953. THE WEIGHING MACHINE, NEAR CAMERA, IS LOWERED INTO TIE GROUND. VIEW FROM NORTH-WEST CORNER, TAKEN APRIL 2ND.

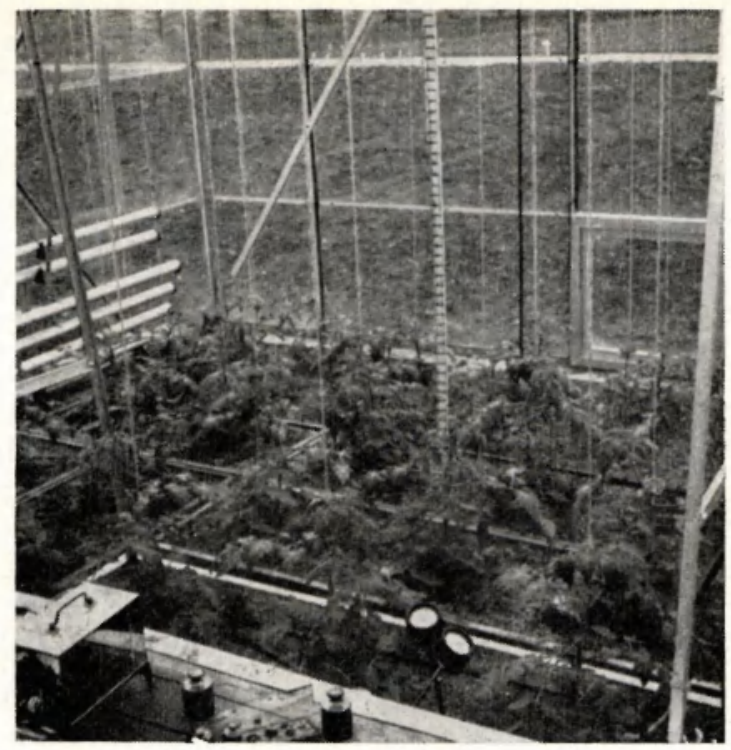

(c) Tomatoes, 1953. To reduce the effects of incomplete cropping of the house and insufficient guarding of the experimental plants the weighing machine was lowered into the ground. This also reduced the effect of temperature variations on the reading of the machine. Part of the crop, which in this case covered about $65 \%$ of the total area of the house, is shown in Figure 7. Some results obtained from daily observations, Figure 8, show that at the stage of growth represented by Figure 7 the transpiration is low, presumably due to incomplete vegetative cover of the soil. But when the plants, some $120 \mathrm{~cm}$ tall, completely shade the soil high transpiration rates are obtained; in contrast to the 1952 experiment however, this transpiration is generally less than the corresponding radiation owing to the larger area of plants in the house. Figure 9 shows the results obtained when hourly measurements were made on this crop over a two day period. It is observed that the transpiration appears to lag slightly behind the radiation, and at night it is small.

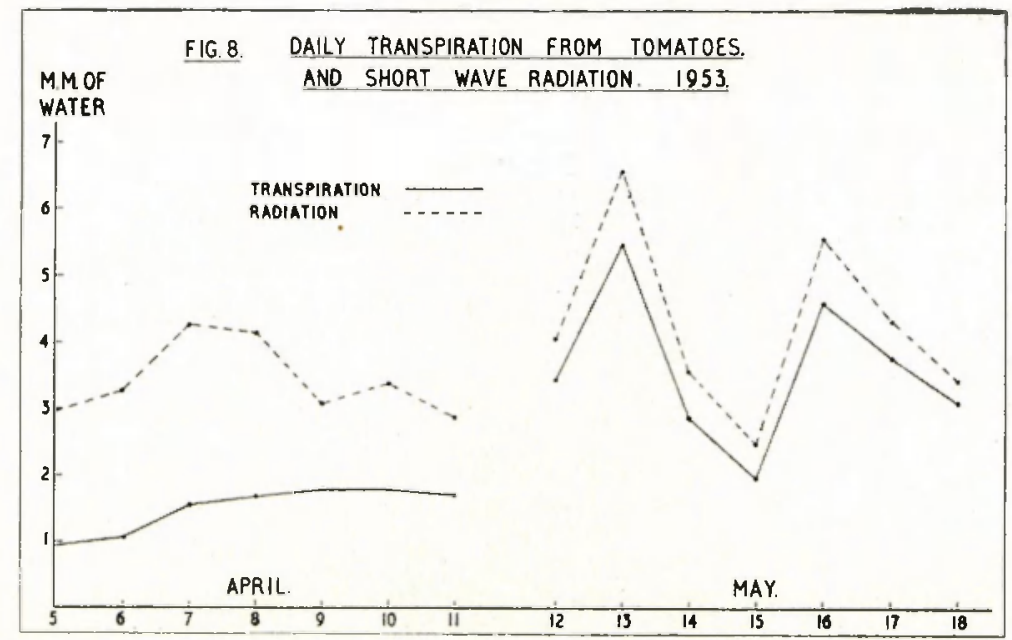




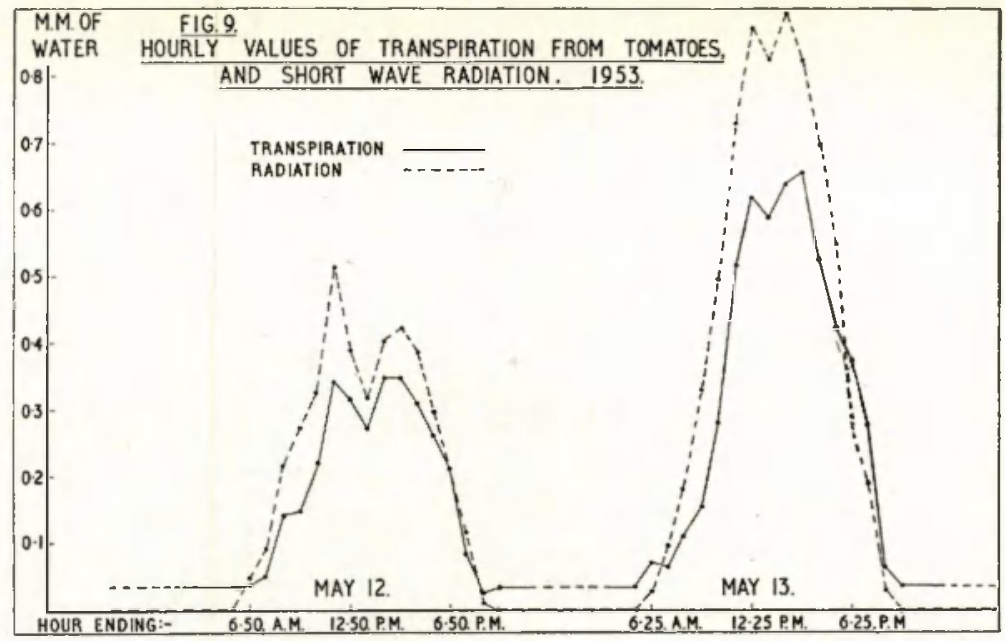

Random errors in the measurement of transpiration amounted to about $\pm 3 \%$, smaller than those for the previous year; the error in the radiation measurement - again obtained by visual integration of the thermopile e.m.f. record was $\pm 4 \%$ as before.

(d) Carnations, 1954. The experimental plants in the weighing machine box are shown in Figure 10 together with part of the surrounding crop, the whole covering about $65 \%$ of the total glasshouse area. Results of daily and hourly measurements are plotted in Figures 11 and 12. Again it is seen that the transpiration is low compared with the radiation until the crop completely shades the soil. A remarkable feature is the high correlation of the radiation and transpiration values for June, although for the reasons stated in (a) above the numerical agreement must be accidental. It suggests however

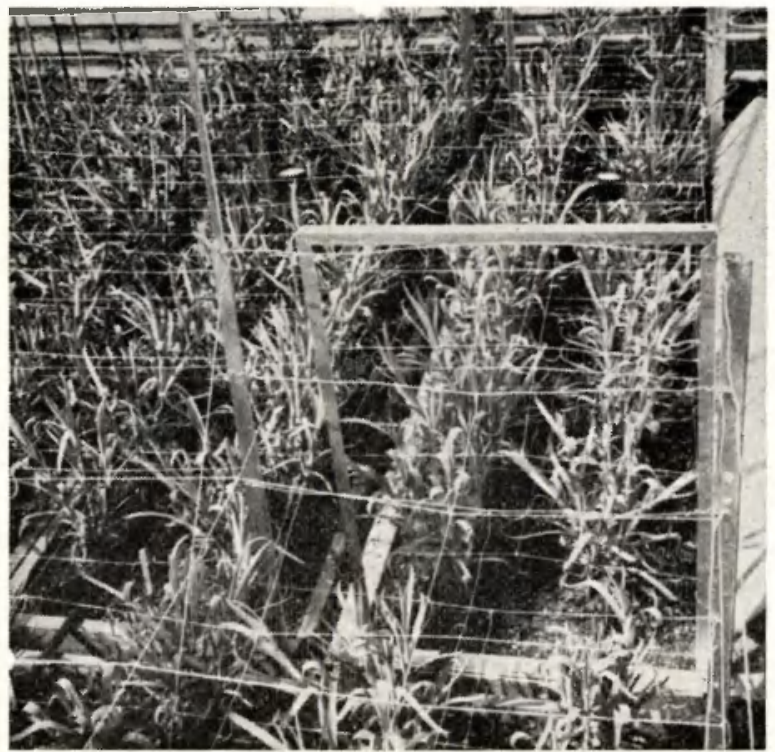

FIG. 10. VIEW FROM EAST SWE OF HOUSE OF CARNATIONS IN WEIGHING MACHINE BOX (ON RIGHT) AND PART OF THE SURROUNDING Cror.

Photograph T.AKeN ON JUNE 7TH 1954. 
that the effect of ventilation on transpiration may have been less for the carnations than for the fully grown tomato plants. Ventilation measurements were carried out during the experiments on the hourly variations of transpiration and radiation, in addition to measurements of air and soil temperature but it has not yet been possible to use the results to determine all the terms in the energy balance equation.
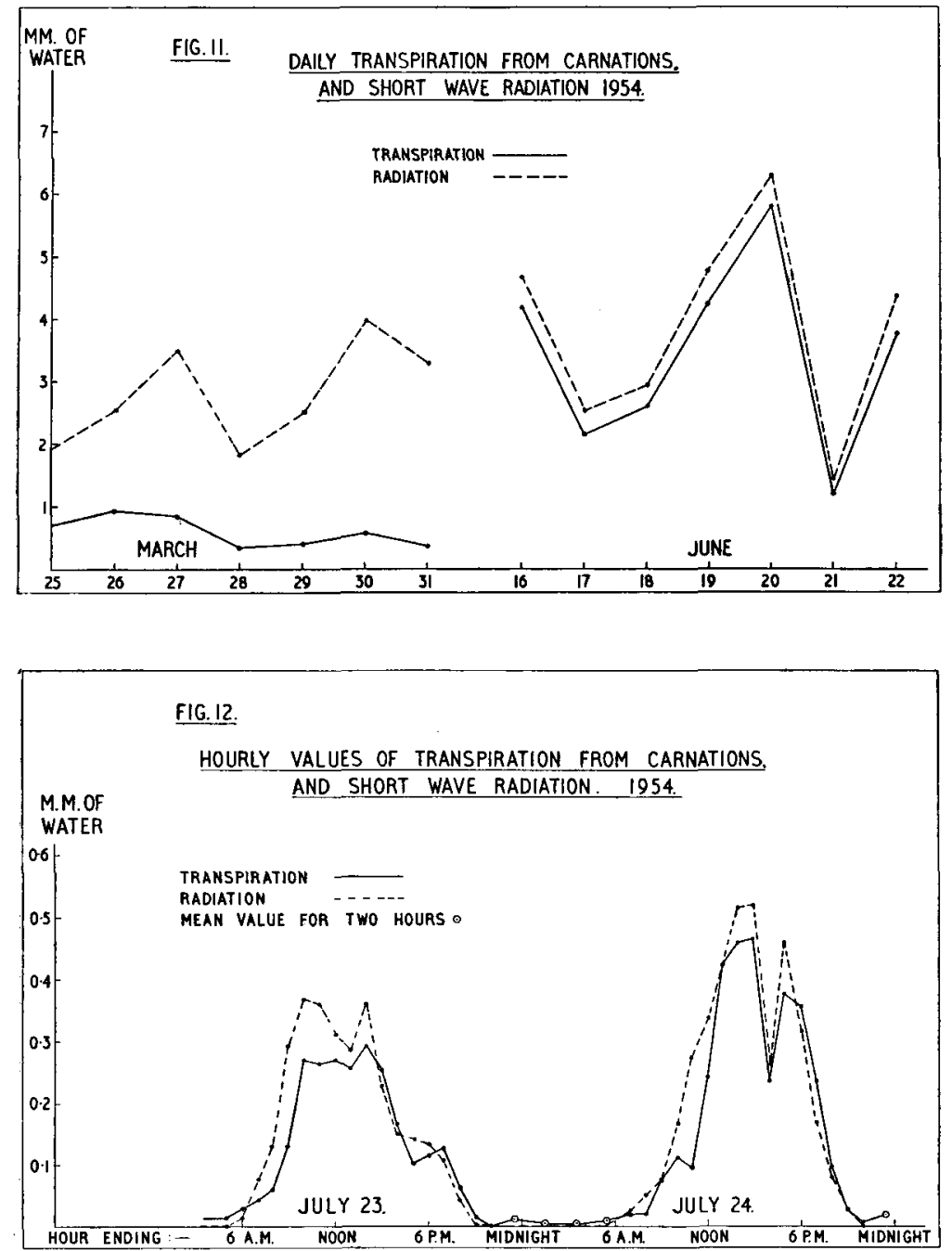

The accuracy of the measurements on carnations was about the same as in (c) above. The use of a magnetic amplifier and integrating motor eased the radiation calculations enormously, but owing to slight zero drift and changes in gain, were only a little more accurate.

\section{Conclusions}

The equipment described enables measurements of transpiration and radiation to be made with fair accuracy over periods as short as one hour, and is 
very convenient for daily measurements. However the weighing machine, which was originally designed for a quite different purpose, did not permit adequate "guarding" of the test plants, but by lowering it into the ground and increasing the cropped area of the house more valuable results were obtained.

\section{ACKNOWLEDGEMENTS}

The work described was carried out under the supervision of Mr. L. G. Monus. Mr. J. D. Postr.ethwaite was responsible for the culture of the plants, and with Mr. R. I. EDwards assisted in taking the measurements. This paper is published by permission of the Director, National Institute of Agricultural Engineering, (Beds., England).

\section{REFEUENCES}

Pevaran, H. L. : Proc. Roy. Soc. 193 A (1948) 120.

Thornthwaite, C. W.: The Geogr. Rev. 38 (1948) 55.

Vries, D. A. ide and R. H. A. VAN Duin: Neth. J. Agr. Sci. 1 (1953) 27.

Wijk, W. R. vax, D. A. de Vlies and R. H, A. vaN Dulv : Neth. J. Agr. Sci. 1 (1953) 53. - -, - - Neth. J. Agr. Sci. 2 (1954) 105.

\section{DIE ÖSTERREICHISCHE LYSIMETERANLAGE}

\section{B. RAMSAUER}

Bundesministerium für Land- und Forstwirtschaft, Sektion IV, Wien, Österreich

Im Bundesversuchsinstitut für Kulturtechnik und Technische Bodenkunde in Petzenkirchen, Niederösterreich, ist seit einigen Jahren eine Lysimeteranlage in Betrieb. Ihre Merkmale sind :

1 I m²-flächige Kästen, 1,30 $\mathrm{m}$ tief, auf Böden in natürlicher Lagerung gefüllt. Die Füllung erfolgte ähnlich wie bei Stechzylindern, jedoch durch Überschieben eines vorbearbeiteten Bodenkörpers. Der Kastenboden wird mit Hilfsnuten unter Abschneiden des Bodenkörpers eingetrieben und verschweisst. An die im Boden befindlichen Schlitze werden zur Abfuhr des Sickerwassers mit groben Sand gefuillte Rinnen angeschweisst und der Kasten sodann in den vorbereiteten Schacht eingesetzt.

2 Die Kästen haben vorne einen mit Glas abgedeckten Schauschlitz, um den Boden beobachten zu können.

3 In $5 \mathrm{~cm}, 15 \mathrm{~cm}, 30 \mathrm{~cm}, 50 \mathrm{~cm}, 100 \mathrm{~cm}$ Tiefe sind Thermoelemente eingebaut, die täglich dreimal abgelesen werden.

4 In den gleichen Tiefen werden Feuchtemesser eingesetzt.

5 Um die im natürlichen Boden vorhandene Bodenfeuchte auch im Lysimeter zu erreichen, kann bei Feuchtigkeitsmangel durch eine über dem Kastenboden eingebaute Filterkerze Wasser auf kapillarem Wege von unten aus zugeführt werden.

6 Jeden Morgen $7^{\mathrm{h}}$ früh werden die Kästen gewogen. Hierzu wird eine Waage auf einem Geleise über die Kästen geschoben und diese gewogen. Genauigkeit $0.1 \mathrm{~mm}$ Niederschlag.

7 Aus Differenz Niederschlag - (Abfluss + Bodengewicht [Speicherung]) wird die Verdunstung ermittelt. 